\title{
ECOPRENEUR: Bridging the Gap between Conventional Teaching and Learner Achievement
}

\author{
Nalini Arumugam ${ }^{1, *}$, Mohamad Idham Md Razak², Asha Latha Bala Subramaniam ${ }^{1}$, \\ Sivajothy Selvanayagam ${ }^{1}$, Mohammad Radzi Manap ${ }^{1}$, Mohammad Hariri Bakri ${ }^{3}$ \\ ${ }^{1}$ Academy of Language Studies, Universiti Teknologi MARA Shah Alam, Shah Alam, Malaysia \\ ${ }^{2}$ Faculty of Business Management, University Teknologi MARA Melaka, Malacca, Malaysia \\ ${ }^{3}$ Faculty of Technology Management and Technopreneurship, University Teknikal Melaka, Malaysia
}

Received September 28, 2020; Revised November 24, 2020; Accepted December 6, 2020

\section{Cite This Paper in the following Citation Styles}

(a): [1] Nalini Arumugam, Mohamad Idham Md Razak, Asha Latha Bala Subramaniam, Sivajothy Selvanayagam, Mohammad Radzi Manap, Mohammad Hariri Bakri , "ECOPRENEUR: Bridging the Gap between Conventional Teaching and Learner Achievement," Universal Journal of Educational Research, Vol. 8, No. 12A, pp. 7981-7991, 2020. DOI: 10.13189/ujer.2020.082586.

(b): Nalini Arumugam, Mohamad Idham Md Razak, Asha Latha Bala Subramaniam, Sivajothy Selvanayagam, Mohammad Radzi Manap, Mohammad Hariri Bakri (2020). ECOPRENEUR: Bridging the Gap between Conventional Teaching and Learner Achievement. Universal Journal of Educational Research, 8(12A), 7981-7991. DOI: 10.13189/ujer.2020.082586.

Copyright@2020 by authors, all rights reserved. Authors agree that this article remains permanently open access under the terms of the Creative Commons Attribution License 4.0 International License

\begin{abstract}
In $21^{\text {st }}$ century education, it is imperative for educators to exploit technology in order to meet the evolving education needs of the current generation through greater access to knowledge. The researchers cum educators supplemented the conventional-based classrooms teaching of entrepreneur education with a customized home-based and interactive e-learning platform, ECOPRENEUR, to increase learner participation, engagement and achievement. The research employed a mixed method approach to elicit data from 385 undergraduates from an established public university in Malaysia to determine the efficacy of the e-learning platform as a supplementary learning tool in the teaching of Technology Entrepreneurship. Findings reveal that the intervention supplementary learning platform improves students' overall grades in Technology Entrepreneurship: $\mathrm{m}=44.04$ in the pre-test and $\mathrm{m}=53.63$ in the post-test. Paired sample test results demonstrate a statistically significant grade outcome $(\mathrm{t}=28.679 ; \mathrm{n}=385 ; \mathrm{p}=.000)$. Further findings reveal that the male students in the study secured higher grades with a mean of 55.72 compared to female students with a mean of $52.26(\mathrm{p}=.000)$ in the post-test. Both pre and post-test scores show that students from the Faculty of Computer Science and Mathematics outperformed (pre-test mean with 45.76 and post-test 56.69) students from the Faculty of Plantation and Agro
\end{abstract}

Technology (pre-test $\mathrm{m}=42.29$ and post-test $\mathrm{m}=50.51$ ), thus indicating that motivation and expertise in information and communication technology to navigate the platform play a major role in determining its efficacy.

Keywords ECOPRENEUR, e-Learning Platform, Learner-Centric, Interactive, Learner Engagement, Communication Technology

\section{Introduction}

Effective learning must incorporate $21^{\text {st }}$ century skills that develop competencies such as collaboration, communication, digital literacy, critical thinking, and problem-solving to help students transition from learning institutions into the workforce. Technological changes have transformed the education landscape allowing for $24 / 7$ access to immediate information, increased connectivity, and shared web-based information. Thus, it is imperative for educators to exploit technology and its impact on $21^{\text {st }}$ century education to support an engaging and bespoke learning environment in order to realise the evolving educational needs of the current generation to be lifelong learners with greater access to knowledge [1]. 
E-learning engages the Internet and other relevant education platforms to design materials for teaching and learning, standardise courses and promote content mobility through numerous communication devices [2]. In addition, studies [3, 4,] underscore the importance of e-learning to support and improve learning through the incorporation of information and communication technology to complement conventional teaching in classrooms, online learning or a blended approach.

The e-learning method, relevant to teaching and learning (T\&L), is described as learner-centric as it involves a system that is interactive, self-directed, and customizable. These features are integral aspects to influence learning [5]. With an open-learning environment, learners are encouraged to seek out information that will help them strengthen their understanding of a given topic. This learner-centric model parallels the learning pedagogies revolving around constructivism and cognitivism that stress the notion students learn best when they can rigorously participate in their own learning endeavours and knowledge building, rather than become passive beneficiaries of information [6, 7].

E-learning, which offers diverse learning interactions, and employs technology, assists learners to develop a broad understanding of subject content and skills. An environment infused with limitless sensory input and enriched by an assortment of audio, written and visual choices enhances learning. Comprehensive learning experiences take place through a curation of content which help learners to increase their focus and execute better control over what and how they self-learn. Literature supports that autonomous learning fosters self-paced asynchronous learning, increases satisfaction and decreases stress [8, 19, 10, 11]. In addition, e-learning motivates learners to interact with others, and to exchange and respect different point of views, thus sustaining learning. Research stresses that e-learning provides opportunities for interactivity between students and teachers during content delivery as it enables easy collaboration for knowledge-sharing [12]. Based on these findings, a crucial factor required to ensure the efficacy of e-learning is to employ an ideal hybrid of blended learning, so that courses can exploit the strengths of online and traditional learning [13]. However, the successful incorporation of e-learning with face-to-face teaching in the classroom is determined by several factors which include technology, lecturers' traits, learners' demographics, perceptions and attributes. Technology introduced in e-learning should also be manageable and not exacerbate a digital divide which could lead to frustration and negative emotions among the users of an e-learning platform [14].

\subsection{Problem Statement}

Technology Entrepreneurship (ENT600), which is a dynamic course offered in University Technology MARA
(UiTM), equips students with practical knowledge to establish a new enterprise or business and develop innovative ideas by being selective, critical and creative to use readily available resources. Undergraduates with sufficient knowledge and skills related to concepts and processes relevant to economics and entrepreneurship are also required to identify technology-based business opportunities and prepare technology venture blueprints to achieve the learning outcomes of the course. Obtaining a pass in the subject is mandatory for graduation. However, the failure rate for the course is high $(\geq 60)$ because for many ENT600 undergraduates in UiTM, Melaka grasping new terms, concepts and applications in economics and principles of entrepreneurship pose multiple challenges. A strong foundation in the knowledge and skills of economics and entrepreneurship is essential to enable learners to: (1) apply a number of economic and entrepreneurship concepts related to daily events across all levels (individual, household, society and country), (2) expand their understanding on economics as a discipline, (3) develop a responsible attitude to make prudent decisions that have international and national economic consequences and (4) foster problem-solving, analytical, communication and persuasion skills essential for success in the current employment market.

Pertinent feedback from students revealed that their poor performance in the subject is due to conventional classroom teaching methods which affected input retention. Furthermore, the heavy reliance on prescribed textbooks and minimal usage of technology-based tools disengaged learners. However, the conventional teacher/lecturer-based approach cannot be side-lined unless it is consolidated with a robust online environment which takes advantage of multiple instructional strategies. Research points out that traditional classroom-based learning and e-learning courses impact learner achievement optimally only when there are positive interactions between the environment and the learners to alter their perceptions and involvement [15]. This blended approach increases the likelihood of successful learning experiences for heterogeneous learners [16]. In the conventional ENT600 classrooms, the different abilities and learning styles of the students were rarely considered. Thus, this study aims to investigate the efficacy of an interactive e-learning platform to increase learner engagement among undergraduates who have different learning abilities and interest.

As such the researchers have set out to answer the following questions:

1. How do students perceive ECOPRENEUR as an e-learning platform to learn Technology Entrepreneurship?

2. How does the e-learning platform and its contents impact students' academic performance?

3. Is there any significant difference between male and female students in their achievements through the use of the e-learning platform? 
4. Is there a significant difference in achievements between faculties through the use of the platform?

\section{Methodology}

This study adopted a mixed method approach to elicit data and involved three phases. There were ten (10) ENT 600 groups at the university, consisting of 385 undergraduates from the Faculty of Computer and Mathematical Sciences (194 students) and the Faculty of Plantation and Agro Technology (191 students) who have little or no background knowledge on business and entrepreneurship.

This study adapted Hannafin and Peck's Model [17] which incorporates a three-phase process (Figure 1). This model helped to design the contents of the course, set the learning environment and gauge the effectiveness of the module (ENT600) on an e-learning platform. In Phase 1, students' opinions and comments provided feedback to identify the gaps that exist between their learning preferences and what happens in reality in the ENT600 classrooms. In a constructivist approach, needs evaluation is essential to analyse the learning materials, content, and media for e-learning programs. Furthermore, it is beneficial in the development of e-learning strategies and provides vital information about the technology and other support services needed for an e-learning program. Through a comprehensive needs assessment process, the researchers were able to develop an e-learning platform to effectively and systematically achieve the learning goals of ENT600 and meet the learning preferences of the students.

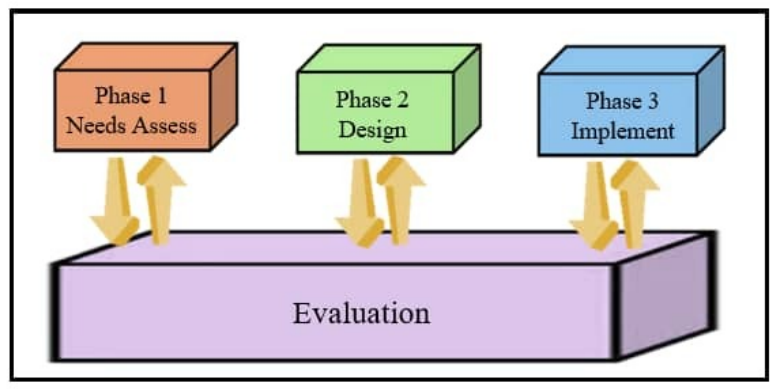

Figure 1. Hannafin and Peck’s Design Model

\subsection{Phase 1 (Needs Assess)}

A survey to identify the main difficulties encountered by students when learning ENT600 was conducted using Google form. Feedback from 385 University Technology of MARA (UiTM), Melaka undergraduates indicated the following reasons for poor performance in the subject:

a). Lessons were not interactive and teacher-centric.

b). Learning resources were restricted to recommended textbooks.

c). Additional resources to support content delivery were poorly curated.

d). Reference resources were not easily accessible.

This valuable feedback stressed the importance to introduce entrepreneurship lessons which are practical and organized in modules with provision for a variety of instructional materials including instructional technologies in T\&L. This prompted the researchers to develop an Interactive Digital/e-Learning Platform (ECOPRENEUR) to provide learners of ENT600 the opportunity to exploit its multi-sensory features and navigate the learning tool independently to help address their specific learning gaps and goals. The user-friendly platform (Figure 2), which not only increases information and technology literacy but also content mastery, is easily accessible through multiple devices like computers, tablets or smartphones for learners to secure similar online learning experiences. The platform supports conventional-based classroom teaching with the inclusion of notes, videos, biographies, comics, case studies, chat room and technical support to increase learner participation and achievement.

\subsection{Phase 2 (Design)}

The ECOPRENEUR e-learning platform is a hands-on and interactive learning tool to complement classroom-based teaching. The ENT600 modules are designed to adopt a personalized learning approach based on the syllabus developed by curriculum designers and policy makers in UiTM. The platform utilises an intuitive interface (Figure 2) and its subject matter comprises topics and exercises organized for a 14-week course (i.e.one semester) to be delivered through PowerPoints presentations, notes, YouTube videos, articles, quizzes, supplementary exercises and a summary of each topic to reinforce content mastery. Although, the content relies heavily on the university syllabus to prepare students for their final examination, the platform encourages experiential learning to promote learner empowerment and reduce a teacher-centred approach in T\&L. Chat rooms are provided to support student to student and student to lecturer interaction outside of the classroom. Furthermore, ECOPRENEUR adopted Kristof and Satron's suggestions [18] which emphasise the importance of incorporating suitable screen layouts, backdrop colours, font size, graphs, visuals, and animations to optimize learner engagement. 


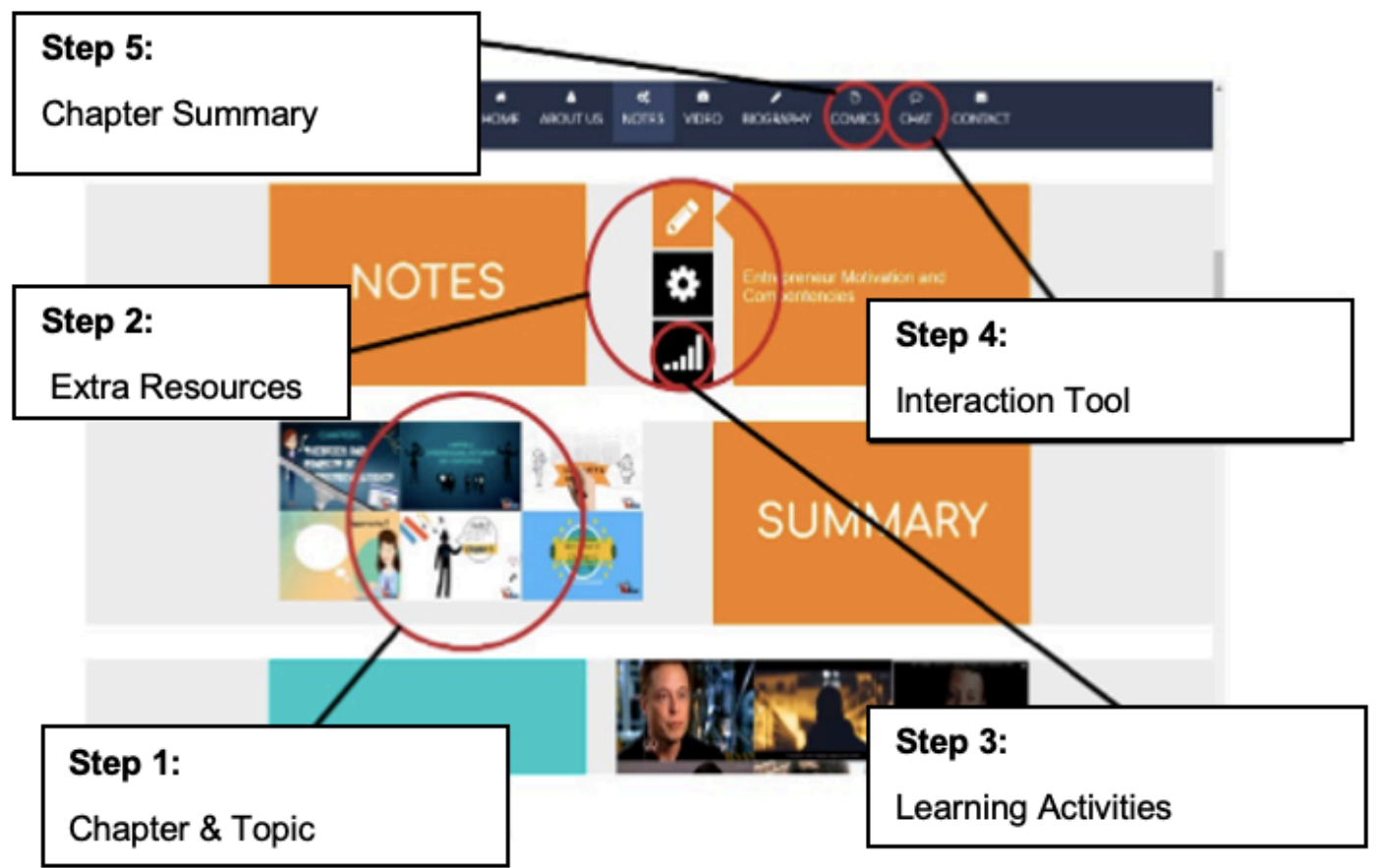

Figure 2. ECOPRENEUR Interface

\subsection{Phase 3 (Implement)}

In this phase the researchers tested the efficacy of the e-learning platform (ECOPRENEUR) to develop students' knowledge and skills on the subject of Technology Entrepreneurship. All the ten (10) ENT 600 groups at the university attended face-to-face lectures for 1.5 hours per week and made use of the platform to reinforce learning prior, during and post lessons from September 2019 to January 2020 to complete a 14-week module. In week 2, a pre-test was conducted to assess students' competency in the course. The post-test was administered in week 13 of the semester after students were exposed to a combination of teaching strategies integrating the e-learning program and traditional classroom teaching practices. This was followed by distributing a survey using Google form to identify the ETN600 students' perception of the platform. Several learners in the structured interview said there were extremely satisfied with the e-platform because the diverse presentation of the content especially the cartoon stimuli, interactive videos as well as lecture notes on concepts and theories were relatable, fun and interesting. In addition, 24/7 accessibility to materials was favourable as it promoted self-paced learning to reach desired learning goals or outcomes. The digital form of the input or content was also praised for being more engaging compared to textbooks or lecture notes in hard copies and the quick retrieval of information from a digital repository via any technological devices added appeal.

\section{Results and Discussion}

ECOPRENEUR, an interactive e-learning platform, was employed to complement classroom-based teaching in ENT600 at Universiti Teknologi MARA, Melaka to improve students' understanding and application of principles in Technology Entrepreneurship. Table 1 shows the responses of the learners (from the Faculty of Computer and Mathematical Sciences (194 students) and the Faculty of Plantation and Agro Technology (191 students).

\subsection{Research Question 1}

How do students perceive ECOPRENEUR as an e-learning platform to learn Technology Entrepreneurship? 
Table 1. Students' Feedback on ECOPRENEUR

\begin{tabular}{|c|l|c|c|c|c|c|}
\hline No & \multicolumn{1}{|c|}{ Statement } & SA $\%$ & A $\%$ & U $\%$ & D $\%$ & \\
\hline & ECOPRENUER.. & & & & \\
\hline 1 & helps with input retention & 5 & 95 & 0 & 0 \\
\hline 2 & increases understanding of concepts \& principles & 5 & 95 & 0 & 0 & 0 \\
\hline 3 & reinforces classroom learning & 5 & 95 & 0 & 0 & 0 \\
\hline 4 & is just another online class & 0 & 18 & 5 & 65 & 12 \\
\hline 5 & is engaging and fun & 5 & 95 & 0 & 0 & 0 \\
\hline 6 & is relevant \& useful to the course & 9 & 91 & 0 & 0 & 0 \\
\hline 7 & is time consuming & 8 & 12 & 0 & 55 & 25 \\
\hline 8 & provides time-flexibility in learning & 12 & 88 & 0 & 0 & 0 \\
\hline 9 & allows me to learn independently & 10 & 83 & 7 & 0 & 0 \\
\hline 10 & is confusing with many instructions & 0 & 12 & 12 & 52 & 24 \\
\hline 11 & encourages group discussions through its chat rooms \& & 6 & 94 & 0 & 0 & 0 \\
\hline 12 & increases my work & 10 & 25 & 8 & 45 & 12 \\
\hline 13 & enhances critical thinking skills & 20 & 80 & 0 & 0 & 0 \\
\hline 14 & is not suitable for group work & 15 & 25 & 5 & 42 & 13 \\
\hline 15 & helps with exam revision & 15 & 75 & 5 & 5 & 0 \\
\hline
\end{tabular}

(SA-Strongly Agree, A-Agree, Unsure) (D- Disagree, SD-Strongly Disagree)

The findings in Table 1 reveal that students (100\%) responded favourably to the use of ECOPRENEUR to improve test scores since input retention was greater. $95 \%$ agreed that the platform was advantageous for exam revision. These findings are consistent with other research findings which point out that e-learning improves academic performance and expands learning. For example, the implementation of an e-learning system (Moodle) at the Faculty of Administration, University of Ljubljana reflected a significantly higher grade average in students' performance in the exams [19]. Additionally, these results match those of [20], [21], [22] who agreed that e-learning has a positive effect on the academic achievements of the students. Furthermore, Dobbs, Waid and del Carmen [23] listed positive student perception of online learning as one of the factors for students to achieve better grades in their assessments. Therefore, student readiness and perception of e-learning are significant predictors of student course performance.

The researchers also conducted unstructured interviews randomly to corroborate their findings. Student 54 shared that she enjoyed having unlimited access to the platform throughout the course. Unlike traditional settings in the classroom, she commented that the extensive use of online resources and free materials on the platform helped her to save time and fulfil all her test requirements. The study also noted that students (100\%) found the materials included on the platform helpful to increase their understanding of concepts and principles of the course, consequently, reinforcing classroom-based learning. The materials presented in the form of videos, comics, biographies and case studies were viewed as relevant and beneficial. Student 208 indicated that the platform not only provided materials for ENT600, but also motivated learners to make the most of every exercise provided: "We saved time just by using all the relevant materials made available to us."

According to Alismail [24] e-learning is a powerful tool as it provides direct access for learners to acquire information and knowledge by themselves. Unlike classroom teaching, online learning enables students to access subject content multiple times, and this reinforces what has been previously learnt in the classroom [25]. The author also asserted that this is critical during revision or when preparing for an exam. Moreover, findings from another study revealed that students who were taught via e-learning devices, such as an interactive whiteboard in their teaching groups had performed better in the class tests compared to groups that used traditional projectors and projection screen in the classrooms as they found these e-learning tools more stimulating and applicable [4]. Lee [26] found that perceived usefulness has an immediate positive outcome to the utilisation of e-learning while perceived ease of use and perceived enjoyment have a productive outcome on the purposeful use of e-learning.

All of the respondents in the study found ECOPRENEUR to be engaging. They were able to share insights on the content or a given task with other peers on the platform (via a chat room) and their interest was sustained through input retention/expansion, independent learning and reflection which are crucial aspects to develop critical thinking skills. Chan et al. [27] concurred that students become active learners when they learn autonomously and increase their analytical skills. 
Additionally, students become captivated by stimulating e-learning content and exercises on videos which are fun, animated and auditory. Liam and Huang (2002) as cited in Borstorff and Lowe [28] also established that a multimedia learning environment improves mental focus because images, video and animations alongside a text stimulate the brain.

The study concluded that an e-learning platform like ECOPRENEUR is a system that provides time flexibility to promote self-directed learning. This is evident when $88 \%$ of the respondents agreed and $12 \%$ strongly agreed to the statement that 'It promotes independent learning'. The reason is e-learning applications including programmed instructions and tutorials allow students to work through the screens at their own pace and at their own time, thus increasing learner agency. Flexibility in planning their own learning schedule is an advantage in e-learning as it does not interfere with other work [29]. The online learning environment promotes learner empowerment, providing students the opportunity to learn new concepts when they feel they are ready or when they feel it is necessary, without being confined to space and time, as is the case with the traditional classroom environment [7]. Students have more flexibility in deciding when, how and with what input and tasks they wish to engage in, which consequently enables them to monitor and alter their behaviour and actions concerning the specific learning context [30].

Some of the negative feedback based on the questionnaire included 'ECOPRENEUR is time consuming' (20\%) It is evident that students do not wish to sit through long e-learning sessions, particularly if they find the course challenging. Hence, it is wiser to break the e-learning course up into "bite-sized" modules so that online learners can access them at a time most convenient for them. Further probing revealed that poor WIFI accessibility was a problem from time to time, especially when some students relied mainly on mobile data for Internet connectivity.

Another negative comment was "ECOPRENEUR is confusing with many instructions". Also 35\% of the students indicated that the learning tool increased workload. This indicates that some students may require digital literacies to participate successfully and effectively in an e-learning environment. In addition, in reviewing current e-learning platforms, there are various criticisms of the quality of the e-learning systems presently being used, such as usability problems, slow performance, institutions being unable to customise the existing platforms to fit students' needs and having a more teacher-centric online system rather than a learner-centric one [31].

About $40 \%$ agreed that 'the platform is not suitable for group work and another 5\% were 'unsure'. While many enjoyed learning through this platform, students No.58 and 189 expressed the feeling of self-isolation when learning ENT600. They admitted that although they were assigned group work, members could not interact much online. Group members often had to call each other or meet face-to face during physical classes on campus. In one analysis of digital learning, researchers found that peer-to-peer engagement is lower in an online learning environment than classroom-based learning [32]. To offer relevant learning experiences in e-learning, lecturers need to develop new skills and knowledge about technologies. Importantly, they should rethink their pedagogies and move beyond using technology as a fancy presentation device.

Findings also revealed that $83 \%$ of the students in the study agreed that the program promotes independent learning. In the e-learning environment, instructors shift from being the primary source of students' knowledge to being the managers of students' knowledge resources [33]. For example, in a traditional classroom setting, the teacher delivers the content to the class and responds to their questions. In contrast, in an e-learning environment, the instructor acts as a facilitator who empowers students to peruse content at their own stride [34]. Students are aware of their learning responsibility in themselves instead of an external source, such as a teacher [35]. Student 128 said "I like to work on my own educational needs. If I do not understand a topic, I can spend more time reading and practicing on that topic. I don't feel guilty holding back my classmates". Chitra and Raj [25] postulated that e-learning creates self-directed learners, who tend to actively engage in the learning processes, such as acquiring information, planning and evaluating the learning activities. Hence, it nurtures self-responsibility to become the administrators of their own learning [36]. Student 55 said: 'There is no one to monitor you, so we had to take charge of our own progress and this motivated me to work hard and be responsible for my own work.' Hence, e-learning also helps to develop learner agency by allowing students to view and review online material in their own time, reflect on their own contributions and alter these at different times based on their own needs or requirements.

Finally, all the respondents in this study agreed with the statement that their critical thinking skills were enhanced. The case-studies and videos on real life problems made available on the platform encourage students to think critically via discussions and devise solutions to the given problems through collaboration and problem solving. These competencies are vital to develop cognitive processes and construction of new knowledge [37].

\subsection{Research Question 2}

How does the e-learning platform impact students' academic performance? 
The impact of learning Technology Entrepreneurship (ENT 600) employing ECOPRENEUR is revealed through the students' performance in their pre and post-tests (Table 2a). The mean pre-test score is 44.04 while the post-test score is 53.63. Paired samples test results demonstrate a statistically significant increase $(t=28.679$; $\mathrm{n}=385 ; \mathrm{p}=.000$ ). There is strong evidence that the use of an intervention supplementary learning program or module improves students' grades in the subject. Here, the mean has increased from 44.04 to 53.63 (Table 2b) which indicates an improvement of 9.59 points at a $95 \%$ Confidence Interval (95\%).

Online learning through the Internet has gained popularity among many technology-driven learners [38]. A study by Thomas et al. [39], which compared students' outcomes between a classroom-based and Internet-based course on construction safety, disclosed that performance in all four assessments of students who completed the course through face-to-face and blended mode was significantly higher than the performance of students merely following classroom-based teaching. Parris and Feely [40] also agreed that online teaching tools helped to produce better grades among students. Similarly, ECOPRENUER helped to address the ongoing issue with student retention for ENT600. Students were able to connect with the course materials through the interactive-learning modules, consequently improving grade outcomes significantly.

\subsection{Research Question 3}

Is there any significant difference between male and female students in their achievements through the use of the e-learning platform?

Tables 3a and 3b present the students' grades based on gender in passing the pre-test. The male students represent a mean of 46.53 and female students, 42.42 . Thus, male students scored higher grades than female students. This confirms there is a significant difference in the grades obtained between male and female students with $(\mathrm{p}=.000)$. Tables $4 \mathrm{a}$ and $4 \mathrm{~b}$ demonstrate the variance in grades between male and female students in the post-test. The male and female students recorded the following respectively: mean=55.72; mean $=52.26$. The male students continued to score higher grades compared to the female students in the subject.

There is a significant difference in the test scores between male and female students with the $\mathrm{p}$ value lower than $p=.05$. Both genders used the platform to learn ENT600; however, the male students scored higher grades in ENT600 compared to the female students. This finding not only contradicts the study done by Arthur and Sam [41] who established that there is no significant difference between male and female students in terms of assessment scores but also that of Siddiq and Scherer [42] who indicated that gender differences in ICT literacy were significant and the use of technology-mediated learning or instruction was beneficial for female students.

Table 2a. Paired Sample Test comparing Pre and Post-tests

\begin{tabular}{|c|c|c|c|c|c|}
\hline \multicolumn{9}{|c|}{ Paired Samples Statistics } \\
\hline \multirow{2}{*}{ Pair 1 } & Mean & N & SD & SD. Error Mean \\
\cline { 2 - 6 } & Post-test & 53.63 & 385 & 13.066 & .666 \\
\hline & Pre-test & 44.04 & 385 & 10.955 & .558 \\
\hline
\end{tabular}

Table 2b. Paired Sample Test comparing Pre and Post-tests

\begin{tabular}{|c|c|c|c|c|c|c|c|}
\hline \multicolumn{2}{|c|}{} & \multicolumn{3}{|c|}{ Paired Samples Test } & \multirow{2}{*}{ t } & \multirow{2}{*}{ Df } & Sig. (2-tailed) \\
\cline { 3 - 6 } & Mean & SD & Std. Error Mean & & & .000 \\
\hline Pair 1 & Post-Test Pre- Test & 9.584 & 6.557 & .334 & 28.679 & .384 & .004 \\
\hline
\end{tabular}

Table 3a. Comparison between Male and Female Students: Pre-test

\begin{tabular}{|c|c|c|c|c|c|}
\hline \multicolumn{7}{|c|}{ Group Statistics } \\
\hline \multirow{3}{*}{ Pre-test } & Gender & N & Mean & SD & Std. Error Mean \\
\cline { 2 - 6 } & Males & 152 & 46.53 & 11.247 & .912 \\
\cline { 2 - 6 } & Females & 233 & 42.42 & 10.470 & .686 \\
\hline
\end{tabular}

Table 3b. Comparison between Male and Female Students: Pre-test

\begin{tabular}{|c|c|c|c|c|c|c|}
\hline \multicolumn{7}{|c|}{ Independent Samples Test } \\
\hline & & \multicolumn{5}{|c|}{ Levene's Test for Equality of Variances } \\
\hline & & $\mathrm{F}$ & Sig & $\mathrm{T}$ & Df & Sig.(2-tailed) \\
\hline \multirow{2}{*}{ Pre-test } & Equal variances Assumed & 4.050 & .045 & 3.652 & 383 & .000 \\
\hline & Equal variances not assumed & & & 3.597 & 306.289 & .000 \\
\hline
\end{tabular}


Table 4a. Comparison between Male and Female Students: Post-test

\begin{tabular}{|c|c|c|c|c|c|}
\hline \multirow{2}{*}{} & Gender & $\mathrm{N}$ & Mean & $\begin{array}{c}\text { Std. } \\
\text { Deviation }\end{array}$ & Std. Error Mean \\
\hline \multirow{3}{*}{ Pre-test } & Males & 152 & 55.72 & 13.318 & 1.080 \\
\cline { 2 - 6 } & Females & 233 & 52.26 & 12.742 & .835 \\
\hline
\end{tabular}

Table 4b. Comparison between Male and Female Students: Post-test

\begin{tabular}{|c|c|c|c|c|c|c|}
\hline \multicolumn{9}{|c|}{ Independent Samples Test } \\
\hline & & \multicolumn{7}{|c|}{ Levene's Test for Equality of Variances } \\
\hline & & $\mathrm{F}$ & $\mathrm{Sig}$ & $\mathrm{T}$ & $\mathrm{Df}$ & Sig. (2 tailed) \\
\hline \multirow{2}{*}{ Pre-test } & Equal variances assumed & .077 & .781 & 2.563 & 383 & .011 \\
\cline { 2 - 8 } & Equal variances not assumed & & & 2.539 & 312.620 & .012 \\
\hline
\end{tabular}

Table 5a. Comparison between Faculties: Pre-test

\begin{tabular}{|c|c|c|c|c|c|}
\hline \multicolumn{7}{|c|}{ Group Statistics } \\
\hline \multirow{3}{*}{ Pre-test } & Faculty & $\mathrm{N}$ & Mean & Std. Deviation & Std. Error Mean \\
\cline { 2 - 6 } & CS & 194 & 45.76 & 12.003 & .862 \\
\hline
\end{tabular}

Table 5b. Comparison between Faculties: Pre-test

\begin{tabular}{|c|c|c|c|c|c|c|}
\hline \multicolumn{7}{|c|}{ Independent Samples Test } \\
\hline & & \multicolumn{5}{|c|}{ Levene's Test for Equality of Variances } \\
\hline & & $\mathrm{F}$ & Sig & $\mathrm{T}$ & Df & $\begin{array}{c}\text { Sig. } \\
\text { (2-tailed) }\end{array}$ \\
\hline \multirow{2}{*}{ Pre-test } & $\begin{array}{c}\text { Equal variances } \\
\text { assumed }\end{array}$ & 13.910 & .000 & 3.143 & 383 & .002 \\
\hline & $\begin{array}{c}\text { Equal variances not } \\
\text { assumed }\end{array}$ & & & 3.149 & 366.030 & .002 \\
\hline
\end{tabular}

Table 6a. Comparison between Faculties: Post-test

\begin{tabular}{|c|c|c|c|c|c|}
\hline \multicolumn{7}{|c|}{ Group Statistics } \\
\hline \multirow{3}{*}{ Post-test } & Faculty & $\mathrm{N}$ & Mean & $\begin{array}{c}\text { Std. } \\
\text { Deviation }\end{array}$ & Std. Error Mean \\
\cline { 2 - 6 } & CS & 194 & 56.69 & 13.629 & .978 \\
\hline
\end{tabular}

Table 6b. Comparison between Faculties: Post-test

\begin{tabular}{|c|c|c|c|c|c|c|}
\hline \multicolumn{7}{|c|}{ Independent Samples Test } \\
\hline & & \multicolumn{5}{|c|}{ Levene's Test for Equality of Variances } \\
\hline & & $\mathrm{F}$ & Sig & $\mathrm{T}$ & Df & Sig. (2-tailed) \\
\hline \multirow[b]{2}{*}{ Pre-Test } & Equal variances assumed & 2.904 & .089 & 4.768 & 383 & .000 \\
\hline & $\begin{array}{c}\text { Equal variances not } \\
\text { assumed }\end{array}$ & & & 4.774 & 376.092 & .000 \\
\hline
\end{tabular}




\subsection{Research Question 4}

Is there any significant difference in achievements between faculties through the use of ECOPRENEUR?

According to $\mathrm{Xu}$ and Jaggars [43] students with lower grade point averages (GPA), particularly challenged learners in social science courses, struggled with poor adaptation to online courses due to issues related to interpersonal interactions, group discussions, peer pressure, etc. Table 5a-5b and 6a-6b illustrate the comparison in test scores between the Faculty of Computer and Mathematical Sciences (CS) and Faculty of Plantation and Agro Technology (FPA).

When an independent sample test was run (refer to Table 6b) to determine if there was a significant difference in the achievements of the students from the two faculties, a 95\% Confidence Interval of the difference between Faculty Computer and Mathematical Sciences (CS) and Faculty of Plantation and Agro Technology (FPA) was recorded. During the interview, several students from the CS faculty shared that they were motivated to use the platform because they were already comfortable using a wide range of digital tools. Furthermore, easy navigation of the platform encouraged increased utilisation of and engagement with the e-program. With $21^{\text {st }}$ century education emphasizing digital literacy, competency in handling technology can be enhanced through e-learning. Xu et al. [44] stressed the importance for online learners to exploit technology to solve problems and be creative. This can be done through an active engagement with unlimited resources on digital learning platforms. In addition, such platforms enable students to gain insights into how to be effective online and communicate with content, peers and lecturers.

\section{Conclusion}

ECOPRENEUR has proven to be an effective e-learning platform/tool by addressing student achievement issues for the subject of Technology Entrepreneurship (ENT600). A mixed-method approach (classroom-based \& blended) in the teaching and learning of this subject has produced a higher number of students who achieve 'pass' or mastery' level. The findings of this research further corroborate how the constructivist framework supports $21^{\text {st }}$ century learning skills in the classroom. The students displayed learner agency in ENT600 as they were given the choice and flexibility of time to achieve the learning outcomes of the subject. Most significantly the interactivity among students allowed for collaboration and reframing of perceptions and schemata to optimise learning. This research also recognises that the success of the e-learning platform is due to the following factors: (1) emotional resonance which is promoted through a safe-learning (non-threatening) environment to provide learners with opportunities to discuss ideas and solve problems, (2) cognitive scaffolding which encourages learners to explore the content on the e-platform to meet required learning outcomes through choice and independent study and (3) aesthetic appreciation for the platform which is reflected by students' positive responses (fun, interesting, not boring, meaningful etc.). Generally, the male students benefited greatly when learning ENT600 on an e-platform, thus contradicting research that have proven that there is no significant difference between male and female students in their test scores or that the female students outperformed the males. Additionally, the students from the Faculty of Computer Science and Mathematics outdid the students from the Faculty of Agro Technology suggesting that confidence or expertise in computer and technology influences learning experiences and outcomes. In general, this e-learning platform is highly recommended to support teaching activities, flexible learning and independent learners.

\section{Limitations}

This study has identified a few limitations. Validation of results requires a larger sample for a comprehensive analysis of scores over several semesters to gauge the efficacy of ECOPRENEUR as a complementary T\&L platform or system. This study only focused on students from the Faculty Computer Science \& Mathematics and Faculty of Plantation \& Agro Technology, UiTM, Melaka. Research can be extended to several other faculties to determine the relevancy and usefulness of this platform.

\section{Recommendations and Further Work}

It is imperative that researchers take on a bandwidth study to investigate the capacity of internet connectivity to support and encourage learning. Difficulties with technology (digital divide) may result in an eventual failure of the platform in the T\&L of ENT600. Further recommendation also includes a study on achievement scores a year into the use of this e-learning platform to determine the validity of the findings of this research. Students have also recommended that self-assessments are integrated at the end of every unit to help gauge their understanding of the content. In addition, gamification and certification of completion in ECOPRENEUR would add value and appeal. In the field of e-learning, gender-, faculty-, course-based research focusing on attitude towards technology, its adoption and impact on test scores would be beneficial. 


\section{REFERENCES}

[1] I. Benta, C. Bologa, C. Dzitac. E-learning Platforms in Higher Education. Case Study, 2nd International Conference on Information Technology and Quantitative Management, TQM. www.sciencedirect.com, 2014.

[2] K. Fry. E-learning markets and providers: some issues and prospects. Education Training, 233-239, 2001.

[3] OECD, E-learning in tertiary education, 2005, http://www.cumex.org.

[4] K.T. Yang, TH. Wang, T.H., Y.C. Kao. How an interactive whiteboard impacts a traditional classroom, Education as Changing, Vol. 16, No. 2, 313-332, 2012.

[5] S. Hubackova, B.F. Klimova. Pedagogical Aspects of eLearning. Language On-line Course and Issues of Learning Styles, Procedia - Social and Behavioral Sciences, 93, 1095 - 1098, 2013.

[6] B.L. McCombs. The Learner-Centered Model: Implications for research approaches. J. H.D. Cornelius-White, R. Motschnig-Pitrik, \& M. Lux (Eds.), Interdisciplinary Handbook of the Person- Centered Approach: Connections beyond Psychotherapy. New York: Springer, 2013.

[7] P. Lam, C. McNaught, J. Lee, M. Chan. Disciplinary difference in students' use of technology, experience in using eLearning strategies and perceptions toward eLearning, Computers \& Education, 73, 111-120, 2014.

[8] S. Maleki, S. Zohre. The impact of E-learning on creativity and learning in physiology course in nursing students of Shahrekord University of Medical Sciences. Future of Medical Education Journal, Vol.5, No.4, 25-29, 2015.

[9] A.F. Algahtani. Evaluating the Effectiveness of the E-learning Experience in Some Universities in Saudi Arabia from Male Students' Perceptions, Durham theses, Durham University, 2011.

[10] N. Songkram. E-learning System in Virtual Learning Environment to Develop Creative Thinking for Learners in Higher Education. Procedia - Social Behavioural Sciences. 674-679, 2015.

[11] J.R. Marc. Book review: e-learning strategies for delivering knowledge in the digital age. Internet and Higher Education, 5, 185-188, 2002.

[12] N. Wagner, K. Hassanein, M. Head, (2008). Who is responsible for E-learning in Higher Education? A Stakeholders' Analysis. Educational Technology \& Society, Vol.11, No. 3, 26-36.

[13] Y. Zhao, J. Lei, B. Yan, S. Tan. What makes the difference? A practical analysis of research on the effectiveness of distance education. 2005. Retrieved from http://ott.educ.ms u.edu/literature/report. Pdf.

[14] K. Khan, K., A. Badii, Impact of E-learning on higher education: Development of an e-learning framework. Life Science Journal, 9(4), 4073-4082, 2002.

[15] Fei Li, Jingyao Qi, Guiwei Wang, Xiaofeng Wang. Traditional Classroom VS E-learning in higher education: difference between students' behavioral engagement, iJET, Vol. 9, No.2, 48-51, 2014.
[16] A.G. Picciano. Theories and frameworks for online education: Seeking an integrated model. Online Learning, Vol. 21 No. (3), 166-190, 2017. doi: 10.24059/olj.v21i3.12 25 doi.org/10.1002/tea.3660020306

[17] M.J. Hannafin, K.L. Peck. The Design, Development and Evaluation of Instructional Software. New York: Macmillan Publishing Company, 1988.

[18] R. Kristof, A. Satran. Interactivity by Design. Mountain View, CA: Adobe. Press, 1995.

[19] D. Umek, N. Keržič, Tomaževič, D. Aristovni, Analysis of Selected Aspects of Students' Performance and Satisfaction in a Moodle-Based E-Learning System Environment December 2015 Eurasia Journal of Mathematics, Science and Technology Education 11(6):1495-1505DOI: 10.12973/Eurasia, 2015.

[20] M. Keshavarz, M. Rahimi, Z. Esmaili. The Effect of E-Learning on Educational Progress of Students. Medical Science of Isfahan University. Torbat Heydarieh Uni. of Medical Science periodical, Vol.1 No.2, 13-22, 2013.

[21] H. Ishmirekha. A study on attitude of college students towards e-learning with special Reference to North Lakhimpur of Lakhimpur District, Assam. International Journal of Information Science and Education, Vol 4, No.1 1-9, 2011.

[22] D. Klein, M. Ware. E-learning: New opportunities in continuing professional development. Learned Publishing, Vol.16, No.1, 34-46, 2003.

[23] R. Dobbs, A. del Carmen, C. Waid-Lindberg. Students' perceptions of online courses: The effect of online course experience. The Quarterly Review of Distance Education, Vol. 18. No.1, 98-109, 2017. https://eric.ed.gov/?id=EJ864 039 .

[24] H.A. Alismail. 21st Century Standards and Curriculum: Current Research and Practice. Journal of Education and Practice, Vol. 6, No. 5, 150-155, 2015.

[25] A. Pauline Chitra, M. Antoney Raj. E-Learning. Journal of Applied and Advanced Research, 3(Suppl.1) S11\&S13, Phoenix Research Publishers, 2018. ISSN 2519-9412

[26] J. Lee. Online support service quality, online learning acceptance, and student satisfaction. Internet and Higher Education Magazine Vol. 6, No. 2, 17-27, 2010.

[27] Y.F. Chan, K.S. Ranjit, J. Baba, E. Parman. Computer Education for Classroom Teaching. Malaysia: McGraw-Hill, 2007.

[28] P.C. Borstorff, S.K Lowe. Students Perceptions and Opinions toward E- learning in the College Environment. Academy of Educational Leadership Journal, Vol.11, No. 2, 13-29, 2007 www.alliedacademies.org/ Publications/ Papers/AEL .pdf

[29] M. Q. Ali, N. Nargis, R. Yasmeen, Z. Iqbal. ICT Use for Effective Teaching- Learning Process in Secondary Schools in Punjab Province. Asian Journal of Social Sciences \& Humanities, Vol. 3 No. 2, 138-143, 2015.

[30] N. Littlejohn, C. Milligan. Learning in MOOCs: motivations and self-regulated learning. The Internet and Higher Education, 29, 40-48, 2016. 
[31] D. Nandi, M. Hamilton, S. Chang, S. Balbo. Evaluating Quality in Online Asynchronous Interactions between Students and Discussion Facilitators. Australasian Journal of Educational Technology, Vol. 28, No. 4, 2012, doi: 10.14742 / ajet.835.

[32] N. Donahue, S. Glodstein. Mentoring the needs of non-traditional students. Teaching and Learning in Nursing Vol.8, No.3, 2-3, 2013. http://dx.doi.org/10.1016/j.teln.201 2.07 .003

[33] B. Kramarski, T. Michalsky. Preparing pre-service teachers for self-regulated learning in the context of technological pedagogical content knowledge. Learning and Instruction, Vol. 20, No.5, 434-447, 2010, http://dx.doi.org/10.1016/j.le arninstruc.2009.05.003

[34] C.B. Teo, R.K.L. Gay. A Knowledge-Driven Model to Personalize e-Learning. ACM Journal of Educational Resources in Computing, Vol. 6, No.1, 1-15, 2006.

[35] O. Demir. The investigation of e-learning readiness of students and faculty members: Hacettepe University Faculty of Education example [Master Thesis]. Ankara: Hacettepe University, 2015.

[36] L. Tomas, M. Lasen, E. Field, K. Skamp. Promoting online students' engagement and learning in science and sustainability pre-service teacher education. Australian Journal of Teacher Education, 40(11), 78-107, 2015. https://doi.org/10.14221/ajte.2015v40n11.5

[37] J. Mueller. Authentic assessment toolbox. Journal of Online Learning and Teaching www.jonathan.mueller. faculty.noctrl.edu/toolbox/ whatisit, 2006.
[38] T. Nguyen. The Effectiveness of Online Learning: Beyond No Significant Difference and Future Horizons. MERLOT Journal of Online Learning and Teaching, Vo. 11, No.12, $309-319,2015$.

[39] H.F. Thomas, R.J. Simmons, G. Jin, A.A. Almeda, A.A Mannos, (2005). Comparison of Student Outcomes for a Classroom-based vs. an Internet-based Construction Safety Course. The Journal of SH\&E Research, Vol. 2, No.1, 1-15, 2005.

[40] J. Parris, M. Feeley, An Assessment of the PeerWise Student-Contributed Question System's Impact on Learning Outcomes: Evidence from a Large Enrollment Political Science Course, 2012.

[41] E. K. Arthur, T. Sam, T., Comparative analysis of male and female students' academic performance in financial accounting: A survey in the cape coast metropolis. International Journal of Social Science and Humanities, 7 (1), 150-164., 2019.

[42] F. Siddiq, R. Scherer. Is there a gender gap? A meta-analysis of the gender differences in students' ICT literacy. Educ. Res. Rev. 27, 205-217, 2019.

[43] D. $\mathrm{Xu}, \mathrm{S}$. Jaggars. Adaptability to online learning: Differences across types of students and academic subject areas, 2013. http://academiccommons.columbia.edu/catalog /ac:157286

[44] D. Xu, W. Huang, H. Wang, J. Heales, Enhancing learning effectiveness using an intelligent agent-supported personalized virtual learning environment: An empirical investigation. Information \& Management, 51(4), 430-440, 2014. 